\title{
The Representation of Modern Domesticity in the Belgian Section of the Brussels World's Fair of 1958
}

The theme of the domestic interior in post-war Belgium has so far remained virtually unexplored. A few academic studies discuss the initiatives and design achievements of the then avant-garde, which included such designers as Marcel-Louis Baugniet, Jules Wabbes, Willy Van Der Meeren, Emiel Veranneman and Pieter De Bruyne. ${ }^{1}$ But there are no studies that explicitly focus on the shape modernity took in the homes of the fifties, a period of acute housing shortage and rapid industrialisation. The limited international reputation of post-war Belgian design and the unstructured internal debate on 'good homes' probably did not help. Whereas in the Netherlands, for example, the post-war domestic reform movement has been examined from the point of view of women's studies, ${ }^{2}$ design history research is being carried out into the influence of socio-cultural phenomena such as the appearance of domestic electric appliances, ${ }^{3}$ and anthropological studies of the interior of the home have been initiated, ${ }^{4}$ research in Belgium is found only in the margins of a few architectural and art history studies, mainly on the work of designers. In response to this, this paper focuses explicitly on the domestic interior in Belgium in the fifties. Its intention is to show how the representation of domesticity in the Belgian Section of the Brussels World's Fair of 1958 was a reflection of the then national discourse on contemporary living. The research presented in this paper is part of a Ph.D. project that aims to shed a light on communications concerning the 'modern' interior in post-war Belgium. ${ }^{5}$ On the whole this project deals with four clusters of actors that operated on a national level: avant-garde groups, socio-cultural organisations, national housing policy and the dwelling-related consumption industry. 
Although it did not have a striking presence in the overall appearance of the event, the home was an important theme at the World's Fair of 1958 or 'Expo 58'. A range of exhibitions - in the Belgian, as well as in the International Section - dealt with dwelling issues. This is not surprising. Showhouses were a very popular exhibition format and offered an adequate formula to express the central theme of the Expo: 'Balance-sheet of the world for a more humane world'. Bearing in mind the human suffering caused by the war and its nuclear apotheosis, the organisers of the World's Fair intended to promote the positive aspects of scientific achievements in the hope they would outshine the risks and dissipate anxiety. ${ }^{6}$ By means of exhibition houses, the hopeful promises of scientific progress for daily life could be illustrated in an almost tangible manner. Images of a modern, comfortable home, fit to house a traditional family, easily created a convincing alibi for a positive belief in the future. As a special form of habitat-presentation ${ }^{7}$ the model home was therefore considered to be a powerful form of public communication. In the Belgian Section of Expo 58 the theme of the home appears in a set of different exhibition groups: the Hygiene and Health Group, the Buildings and Dwellings Group, the Electric and Hydraulic Energy Group, etc. [fig. 1,2] A study of the different approaches to modern domesticity presented by these groups reveals a cluster of barely connecting narratives on contemporary living. These narratives do not necessary contradict each other, but often focus on different habitation issues. Moreover they hardly ever refer to one another or present their approach as part of a more complex domestic problem. This paper argues that the totality of these presentations reflects the then national debate on domestic life. Although not intended as such, the compound image of the modern home projected by the Belgian Section exposes the lack of a coordinating national policy and underlines the increasing importance of modern dwelling as a consuming way or 'style' of living rather than making a substantial contribution to the post-war social and cultural regeneration process that many domestic reformers hoped to encourage. 
Although concrete distinctions are often difficult to make, references to domestic issues were made for different reasons in the Belgian Section of Expo 58, ranging from a means for education in 'good' living, through tools for the representation of the progress made in the Belgian home, to an exhibition or advertisement format for home-related products. In the first two categories - referring to Beatriz Colomina - the house is 'on display'. ${ }^{8}$ This means that the home is the main exhibit and habitation is the central topic. The last category fits Colomina's description of presentations in which 'the concept of the exhibition' is stretched into that of the house. Here the home is mainly used as a communication framework for other, possibly home-related matters. The first category was certainly not the best represented in the Belgian Section of Expo 58. This explains why the Belgian design critic Léon-Louis Sosset complained that 'these elements which contribute to better living, to more comfort and hygiene in the domestic interior' were not given sufficient space at the Expo. ${ }^{9}$ There were only a few home exhibitions of which he, as a 'taste-educator', could approve and, in relation to the generally entertaining nature of the World's Fair, they seemed almost to vanish. Unlike Sosset's critique, this paper not only focuses on the domestic references which were intended to present the progress in the nation's homes or to promote 'good' living (two goals that are closely interrelated). It also discusses the use of model homes as an advertising format for consumer products.

\section{Presenting Ideals of Good Homes and the Progress of the Nation's Homes}

Ideals of good homes and the progress of the nation's homes at the level of the interior were mainly expressed in the Buildings and Dwellings Pavilion, the Social Housing Pavilion and the exhibition

of Belgian interior designers. ${ }^{10}$ As stated above, the barely interrelating model homes presented on these locations reflect the absence of a guiding political programme concerning contemporary domestic living and household design in Belgium. It is true that the Ministry of Public Health and 
the Family - responsible for the realization and supervision of the national housing policy - did invest in certain issues of modern domestic living, but its initiatives came late, were limited and hardly influential.

First of all, post-war housing policy in Belgium was in general characterised by the absence of a strong overall urban and architectural vision. It was invigorated by two new subsidy acts, which were meant to solve the acute housing shortages after the war: the De Taeye act and the Brunfaut act. Each of them had a different political orientation: the first being a Catholic-inspired act, intended to stimulate private ownership and the construction of single-family houses, preferably on separate parcels, the second being a Socialist-oriented act that embraced collective housing. ${ }^{11}$ But, due to an ongoing conflict concerning social housing between the Catholic and Socialist party in government, the Brunfaut act was never an accurate translation of the intentions of the original bill. Instead of providing the means for CIAM-inspired housing developments with, for example, several collective dwelling services, a so-called 'war of amendments' following the proposal of the bill curtailed the act's powers so that it could only allow restricted financial support for the infrastructure and the layout of public areas in social housing projects. ${ }^{12}$ As a result it was mainly the De Taeye act which, from the fifties on, was an instrumental factor in urban development in Belgium. Without the guidance of a structuring urban programme, it became the main reason for the nation's well-known excessive sprawl; a scattered scene of ribbon development and detached houses.

Just as was the case with national housing policy in general, there was no strong guiding political vision concerning domestic design in post-war Belgium. Unlike neighbouring countries such as the Netherlands and Great Britain, the Belgian government did not take on a coordinating role in terms of the development, promotion and distribution of modern household equipment. The activities of the Institut National pour la Promotion de l'Habitation (INPH) - a public institution set up in 1949 exemplify this situation. ${ }^{13}$ This institution was conceived as a study, information and documentation 
centre by the Ministry of Public Health and the Family. It was meant to conduct scientific research at the request of, among other bodies, the national housing societies and credit institutions related to the above-mentioned ministry: the Société Nationale des Habitations et Logements à Bon Marché, the Société Nationale de la Petite Propriété Terrienne, the Fonds du Logement de la Ligue des Familles Nombreuses de Belgique and the Caisse Générale d'Epargne et de Retraite. ${ }^{14}$ Furthermore the INPH had to educate public opinion concerning all home-related problems on a national scale, including the problem of the domestic interior. ${ }^{15}$ In order to do so the institution organised several home exhibitions and published brochures explaining post-war housing policy.

Although the research and conclusions of the INPH concerning the modern home were often pertinent and revealing, they never significantly influenced national politics. In 1950, for instance, the INPH recorded a distressing shortage of 'good-quality housing for the common people, in good taste and at a moderate price'. ${ }^{16}$ It came to this conclusion after it had organised fourteen furniture exhibitions in new housing projects built by the Société Nationale des Habitations et Logements à Bon Marché and the Société Nationale de la Petite Propriété Terrienne. In order to remedy the stated 'problem', the INPH tried to persuade the Ministry of Economic Affairs to have furniture developed specially for the homes built under the new De Taeye and Brunfaut subsidy acts. This project yielded few concrete results, however. L'Habitation, the periodical of the INPH, which had announced the furniture idea in 1950, never mentioned it again. ${ }^{17}$

Lacking strong political guidance, several participants in the Belgian debate on 'good' living developed their activities individually. Their mutual independence is tellingly illustrated by two events that almost simultaneously took place in Brussels in 1950. Within a distance of no more than one mile the Office Provincial des Artisanats et des Industries d'Art du Brabant, and the association of the French-speaking Catholic workers' movement both separately organised an exhibition on the modern home and the use of inexpensive contemporary furniture, respectively called 'Logis 50'/'Schoner Wonen' and 'Le foyer populaire 1950'. ${ }^{18}$ [fig. 2,3] Although the graphic design of the 
two exhibition posters both centre on the silhouette of a house with saddle roof, their remaining iconography clearly expresses the individuality of the two events. 'Logis 50’/'Schoner Wonen’ is advertised by an abstract composition of colours and words, referring to a 'good' avant-garde 'taste' for the home. A pattern of brick walls and a bird's nest on the other hand bring to mind Catholic family values and the traditional single-family house as the cornerstone of society. Although the two organising institutions meant to reach working-class people, they did not collaborate or communicate their ideas. Without referring to one another, 'Logis 50’‘'Schoner Wonen’ was mainly discussed in the avant-garde journals, 'Le foyer populaire 1950' in the periodicals of the Catholic workers' movement. Only the INPH noticed the 'overlap', but its critique did not go any further than the observation that the second exhibition was more popularly oriented than the first. ${ }^{19}$

The debate on 'good' living in Belgium remained severely fragmented during the fifties. Even in 1958, when the Brussels World's Fair created an excellent opportunity to promote or influence the nation's home culture on a broad scale, the collaboration between the participants in the debate on modern living was rather limited. Again, pertinent remarks and suggestions by the INPH had been passed by. As early as 1951 - shortly after the decision to organise a World’s Fair in Belgium - the institute claims to have contacted the national government, as well as the Belgian Ministry of Economic Affairs and the commissioner general and the secretary general of the World Exhibition. ${ }^{20}$ It had made a plea for preserving a large part of the exhibition area for the Belgian housing and building organisations and for the construction of a fully-equipped model-housing district, just as had been the case at the World Exhibition in Liège in 1905 and 1930 and in Brussels in 1910. In 1955 however the INPH had to conclude that its efforts to organise and structure the presentation of national housing issues in the Belgian Section had been in vain. ${ }^{21}$ The subdivision into groups and subgroups, largely imposed by the International Bureau of Exhibitions, implied that the housing theme was divided between at least three different groups - the Urbanism Group, the 
Buildings and Dwellings Group and the Hygiene and Health Group - and was, according to the institute, 'not in keeping with current affairs' ${ }^{22}$ Furthermore, due to the large number of international participants, there appeared to be no place left on the exhibition site for a high-rise model housing district, so a dwelling project outside the expo boundaries had to be considered. The Heysel Model District in the near vicinity of the World's Fair was meant to answer this need, but was unfortunately not completed in time. ${ }^{23}$

\section{The Buildings and Dwellings Pavilion}

The Buildings and Dwellings Pavilion clearly illustrates how even an attempt by a single group to draw up an overview of national housing issues turned out to be problematic. The Buildings and Dwellings Group (Group 37) intended to devote their pavilion explicitly to 'a synthesis of the problem of the home' along with the nation's progress in solving this 'problem'. ${ }^{24}$ Nevertheless it ended up reducing the issue of the modern interior mainly to a problem of technical equipment. Although, in one of its first statements, the committee of Group 37 - led by the modernist architect Léon Stynen and mainly comprising representatives of various national societies of architects, urban developers and building firms - stressed the importance of the 'demographic, economic, social, technical, moral and cultural' aspects of habitation, these topics were only discussed on an urban and architectural level. The group’s theme ‘Architecture and technical progress serving mankind', subtitled 'The construction, arrangement and equipment of dwellings' already indicates the emphasis that was put on the architectural and constructive aspects of the home. As far as the interior was concerned, only the heating, the lighting, the sanitary and the kitchen appliances - each represented as a different subgroup - were paid broad attention, giving the impression that hygiene and comfort in the form of technical appliances are the most important prerequisites for a contemporary interior. For example, the presentation by the Heating Subgroup consisted primarily 
of a dense collection of stoves, stacked on shelves and only referring to the domestic sphere by the presence of a few houseplants. [fig. 5]

The Buildings and Dwellings Pavilion, a project by the architect Charles Van Nueten, was originally conceived as part of a high-rise apartment block on pilotis containing about twenty fullyequipped model flats. ${ }^{25}$ This building was intended to be accompanied by at least one prefabricated and fully-furnished detached single-family house. But, due to restrictions caused by the available site and probably also due to the pressure exerted by the Urbanism Group, the Public Health Group and the organisation of a home exhibition that was planned in the Heysel Model District outside the Expo area, this first plan was abandoned. ${ }^{26}$ Finally the Buildings and Dwellings Pavilion was built as a genuine exhibition hall, comprising two parts. The first part - a steel construction referred to as building A - contained the main entrance and provided space for the presentation of the following subgroups: Architecture, Construction Materials and Techniques, Sanitary, Lighting and Insulation Techniques. Building B was a concrete structure that was connected to building A by a blind footbridge and in which presentations of Kitchen Appliances and Domestic Heating were shown. [fig. 6] On the ground floor there was a restaurant and, in accordance with the very first project for the pavilion, one prefabricated single-family house was erected next to building B.

At first the intention was to take up the building and habitation issues presented by the different subgroups, in a central exhibition area focusing on the home. Here the more documentary sidepresentations of such items as heating and sanitary installations, would be related to the house by means of, among other things, two model interiors and an exhibition of Belgian architecture. This central area however was never completed as the Committee of the Group had intended. Instead of an additional floor for the so-called 'synthesis of the home' this concept was - due to financial limitations and at the request of the individual subgroups - absorbed into the presentations of the subgroups themselves, creating, according to the Board of Administration, a 'tiring circuit' through somewhat 'overloaded' exhibition spaces. ${ }^{27}$ 
Almost ironically, it was the detached single-family house that, in the end, provided the most convincing synthesis of, according to Group 37, what progress could contribute to the modern home. [fig. 7] The popular Flemish magazine Zondagsvriend praised the wooden exhibition bungalow as ‘a clear and broadly accessible example of the contemporary art-of-living' and as ‘a humble and realistic dream house'. ${ }^{28}$ The Francophone newspaper Le Soir also expressed its admiration for the model home and reported on the broad public interest it enjoyed: 'One just has to move in: something a fair amount of visitors certainly dream of, most of all the housewives, after they admired the electronic devices. ${ }^{29}$ In a concluding report the group committee itself described the model home as 'the only remaining trace, albeit a modest one, of an ambitious programme which was meant to fully sing the praises of the contemporary home'. ${ }^{30}$ The exhibition house, made by the building firm De Coene, was indeed a simple, colourful, modular construction, made of prefabricated wooden building materials and characterised - unlike most its catalogue homes - by such clear modernist features as a flat roof, a functional floor plan, wall units, a free-standing hearth, etc. ${ }^{31}$ However, the fully furnished interior of the house had a more complex appearance. [fig. 8] Although this interior, just like the group's exhibition in general, mainly expressed domestic progress in terms of equipment - a sophisticated bathroom, a modern kitchen, etc. - it simultaneously brought up another issue: that of modern design as an exponent of 'good' domestic living. To fit out the house, two kinds of furniture were used: Knoll design, produced under licence by De Coene, and furniture designed by De Coene itself. In the arrangement of the chairs, tables and cupboards a clear distinction was made between the more representative rooms, mainly furnished with Knoll, and the more private ones showing the De Coene products. The privileged position of the products by the American-based firm - which were unanimously appreciated by Belgian modernists - underlined their reputation as international role models of 'good' design. However, as an exponent of 'good' domestic living, Knoll furniture was somewhat ambiguous at the time. Contrary to the affordable, so-called 'social' furniture many modernists aspired to, Knoll 
was exclusive and expensive. In 1958 the firm had already developed into a symbol of the new administrative establishment, furnishing many lobbies and meeting rooms in exclusive business quarters. Simultaneously Knoll had become a symbol of the culturally sound, modern dwelling of the upper classes. ${ }^{32}$ The 'well furnished interior' ${ }^{33}$ of the exhibition bungalow therefore did not simply display 'good' design, but also indirectly referred to the increasingly fashionable side of the modern home.

\section{The Social Housing Pavilion}

References to hygiene, comfort and design in relation to the domestic interior were also present in the Social Housing Pavilion, albeit in a different way. This pavilion was entirely devoted to the presentation of the Family Health Subgroup (Subgroup 2) of the Public Health Group. The chairman of this subgroup was Cyrille Crappe, the secretary-general of the Institut National du Logement (INL), which was established in 1956 and had taken over the activities of the INPH. ${ }^{34}$ Crappe believed, as did the committee of the whole group, that a healthy house was an essential prerequisite for a healthy family. Therefore the presentation in the pavilion focused on the theme of social housing in Belgium. Next to a central INL exhibition stand, which was intended to deal with 'the habitation problem in general', the national building societies and credit institutions presented their recent achievements. ${ }^{35}$

The Family Health Subgroup was part of the classification of the Public Health Group, ranging from the Health of the Individual up to Collective Health. Although it fulfilled a crucial link in this structure, it was the only subgroup whose presentation was situated mainly outside the exhibition area provided for the group. Whereas all other subgroups were presented in Exhibition Hall XI one of the remains of the 1935 Brussels World's Fair - the main Family Health Subgroup display was in the abovementioned Social Housing Pavilion: a project by the architects Jacques Dupuis and Albert Bontridder which was erected in the grounds of the Urbanism Group. ${ }^{36}$ [fig. 9] This overlap 
was of mutual interest to the two groups. As the correspondence between both committees indicates, the Urbanism Group was eager to present the post-war modernist social housing projects on its own terrain, directly linked - by a footbridge - to its own pavilion and thus underlining the importance of social housing as a problem of urban development. The Family Health Subgroup on the other hand was pleased to be able to build its own pavilion, thus creating a larger exhibition space than it would have had in the exhibition hall. ${ }^{37}$ As a frontage and invitation to the Social Housing Pavilion, Subgroup 2 erected a relatively small exhibition stand in Hall XI, mainly focusing on the fight against unhealthy homes, then a crucial theme in the policy of the INL. Apart from the housing projects presented by the national housing bodies and the financial information supplied by the national credit institutions, a large part of the Social Housing Pavilion dealt with the national housing problem in general. In a presentation designed by the graphic designer Lou Bertot, the Family Health Subgroup showed, among other things, a collage of aerial photos suggesting the negative influences of high housing concentrations in the city, a series of pictures of facades and plans presenting the different types of houses from 1800 up to 1958, diagrams of national housing activity and a large model and drawings of the Heysel Model District. The presentation by the INL, situated strategically near the beginning of the exhibition circuit, mainly existed of a series of plywood panels on which the problem of 'good' social housing was tackled, answering such questions as ‘For whom?’, 'By whom?’, 'Where?’, 'How much?' and 'How?' in a cartoon-like manner. [fig. 10] The answer to the question 'How?' or 'How to make a good dwelling?' in particular tells us something about the way the INL approached the domestic interior. This panel showed four words - ‘security', 'beauty', 'hygiene’ and 'comfort' - combined with five pairs of drawings each comparing a 'good' with a 'bad' situation. The only drawings that were related to the interior of the house showed an exemplary modern bathroom next to an oldfashioned, 'bad' example. The other cartoons mainly showed the outside of the home, preferably in green surroundings. 
When it came to the domestic interior, hygiene and bodily comfort were clearly top priorities for the INL, just as they were for the Buildings and Dwellings Group. However, contrary to the latter group, the emphasis in the exhibition in the Social Housing Pavilion was not laid on hygiene and comfort in terms of infrastructure, but in their direct relation to the human body and family life. For example, to emphasise the importance of bodily hygiene, the INL did not show an exhaustive collection of sanitary equipment, as was the case in the Buildings and Dwellings Pavilion. Instead, it depicted a child bathing in a contemporary bathroom opposite a photo of a woman washing her three children in a pre-modern kitchen. [fig. 11] The ideal homes presented in the Social Housing Pavilion were literally 'inhabited’ houses, far more than was the case in the Buildings and Dwellings Pavilion. As an answer to the question 'For whom?' or 'For whom are social dwellings built?' the INL even gave a survey of the kind of model inhabitants it had in mind, often presenting them in a domestic setting. The cartoons showed a boy or a young male in his study, a girl or a young woman at her make-up table, a young couple not yet with children, a couple with two children looking out from what was, probably, a living room, a couple with three children next to a cupboard and two elderly people close to a fire-place. The traditional family structure clearly served as a 'good' example.

As mentioned above, the Social Housing Pavilion also referred to modern furniture design as an aspect of the modern home. But again, it did so differently from the Buildings and Dwellings Pavilion. Eight years after the INPH's suggestion of stimulating the production of Belgian furniture for the post-war houses built with support of the government, the INL organised a national furniture contest. In order to support the law of $27^{\text {th }}$ June 1956, which allowed certain national housing organisations to grant loans for the furnishing of social dwellings and small country dwellings, the intention was to promote the research and the use of so-called 'social furniture' ${ }^{38}$ This term refers to cheap, light, modern designs and combinable furniture-elements that were meant to replace the old-fashioned and unwieldy 'suites' of furniture, especially in the rather compact social dwellings. 
Due to the slow modernisation of the Belgian furniture industry, ${ }^{39}$ the INL initiative was supported not only by the Ministry of Public Health and the Family, but also by the Ministry of Economic Affairs and the Ministry of Foreign Trade and Retailing.

The competitors in the national furniture contest were asked to design furniture for one of the following categories: 'Dining room', 'Sitting room', 'Room for a boy or a girl' and 'Room for the parents' ${ }^{40}$ This selection of rooms is not surprising as it was mainly in these areas of the interior that the classic furniture ‘suites’ were still frequently used. An international jury - including Jaak Penraat and Max Bill - awarded prizes to seven entries divided over the four categories. ${ }^{41}$ The INL publicly presented the winning designs in the course of 1958 on several occasions: for example, in the Social Housing Pavilion, where the furniture was probably exhibited by means of photographs ${ }^{42}$ and in the Exhibition of Urbanism and Dwelling organised by the INL in a new social housing project in Liège, where the winning designs were used to furnish several model flats. On both occasions the issue of 'social furniture' was integrated in the institute's overall plea for affordable, healthy dwellings. In contrast to the Buildings and Dwellings Pavilion, where the question of modern design was tackled more or less by chance, indirectly referring to upper class living standards, the INL incorporated the issue in its social housing policy, mainly underlining the practical and financial advantages of contemporary social furniture.

Although the Buildings and Dwellings Pavilion and the Social Housing Pavilion both stressed the importance of comfort, hygiene and design for the domestic interior, their approaches concerning these issues did not coincide. As stated above, their interpretations of these three terms were quite different and more or less complemented each other. In general, one could say that both pavilions were intended to exhibit the progress made in Belgian domestic life, but addressed a different public. While the Buildings and Dwellings Pavilion seemed to aim at a public of builders, architects and visitors with a certain financial strength, the Social Housing Pavilion focused on a broader social spectrum, hoping to introduce the necessary, supposedly absent cultural knowledge by 
applying approved educational techniques such as the presentation of opposing good and bad examples. The common interests but differing viewpoints of the Buildings and Dwellings Pavilion and the Social Housing Pavilion did not however lead to fruitful discussion. The only official correspondence between the two groups, dating from 1955, concerned the very first project for the Buildings and Dwellings Pavilion and mainly expressed the fear of the Family Health Subgroup that 'the Buildings and Dwellings would take it all' and nothing would be left for them to exhibit. ${ }^{43}$ So, instead of taking the opportunity to tackle common questions regarding the home - such as the domestic interior - together, both groups ended up avoiding any conflict and reinforcing their independence without referring to each other.

\section{The Exhibition of Belgian Interior Designers}

There was only one case in which different presentations concerning 'good domestic living' at the 1958 World's Fair were clearly interrelated. For the exhibition of the work of Belgian interior designers, the Applied Arts Subgroup of the Art and Artistic Techniques Group (Group 2) decided to work together with the INL. This presentation was situated in Exhibition Hall VII, together with all the other participants of the group. Several model rooms were shown in a gloomy gallery: mainly living, sitting and bedrooms. These living areas were completely furnished and among others presented designs selected by the national furniture competition. Moreover the affiliation with the INL was stressed with a separate exhibition stand for the institute.

The collaboration between the Applied Arts Subgroup and the INL was not surprising. Research concerning 'social furniture' had already been a central theme in the work of many Belgian avantgarde designers between the wars. The Cubex kitchen, designed by Louis-Herman De Koninck and the Standax furniture designed by Marcel-Louis Baugniet were designed especially for workingclass people (although they were never used as such). The post-war housing problem, combined with rapid industrialisation, led to a vigorous revival of the 'social furniture' concept in avant-garde 
circles. In 1950, the Formes Nouvelles design group in Brussels was the first organisation to pick up the idea and develop a programme to encourage contemporary Belgian design, to teach the public 'good taste' and to stimulate the national furniture industry. ${ }^{44}$ Later, from 1955 , the Museum of Design in Ghent and its annual 'Salon voor Modern Sociaal Meubel' (Exhibition of Modern Social Furniture) played a central role as a forum for avant-garde design experiments. Because the events organised by this museum were very successful in the years when the Expo was in its preparatory stages, the museum's director, Adelbert Van De Walle, was appointed vice-president of the Applied Arts Subgroup. $^{45}$

The format for the presentation of the Belgian interior designers at the World's Fair was similar to that of the Ghent Exhibitions. First, Belgian designers and production firms were invited to apply for a presentation stand, which, according to the regulations, had to evoke a 'real' domestic interior. Then entries which showed 'a modern, original concept', 'a strong construction and good-quality materials' and 'a reasonable price in relation to production costs' were selected by a team of experts. ${ }^{46}$ As Van De Walle was also a member of the jury of the national furniture competition, it is not surprising that the winning designs in this competition were at the same time accepted for presentation in the exhibition of the Belgian interior designers. The result was a compilation of model rooms furnished with national design products.

While the INL mainly stressed the practical and financial advantages of social furniture, presenting it as part of the national social housing project and the struggle against unhealthy living, the exhibition of the Belgian interior designers first and foremost underlined its cultural ambitions, linking it directly with the arts by the integration of several paintings and sculptures and thanks to the proximity of the fine arts presentation in the same Exhibition Hall. Rather than projecting an ideal family life, as was the case in the INL exhibition, the model interiors in Hall VII were stripped of any direct suggestion of habitation (e.g. the presence of personal belongings), so as to create an unencumbered setting for the presentation of contemporary furniture. Just as in the Ghent 
Exhibitions of the mid fifties, the domestic realm was thus reduced to a series of severe compositions of objects of 'good taste'. However, the designs in Hall VII themselves clearly differed from those shown in Ghent. Compared to the generally playful avant-garde furniture experiments of the mid-fifties and, especially in the context of the lively, styled 'Expo-happening', the chairs, tables, armchairs, cupboards and beds exhibited at the World's Fair had a quite austere and, according to some critics, even excessively stiff appearance. ${ }^{47}$ The furniture in Pieter De Bruyne's room for a young male or female, for example - awarded a prize by the national furniture contest - were characterised by the use of a stern, standard framework of massive ash, with visible joints and filled with possibly lacquered panels. [fig. 12] Apart from the playful use of colours (blue, red, grey and white lacquer), there were no similarities to the generally gay character of the round-edged and boomerang-shaped furniture design of the early fifties. The combination of the overall severe expression of the presentation of the Belgian interior designers and the more sociallyoriented approach of the INL certainly produced one of the most consistent and versatile models of 'good domestic living' in the Belgian Section of Expo 58. But to experience the full picture the public had to visit two different sites. Furthermore, according to Sosset, the location of the exhibition of Belgian interior designers was very unfortunate: next to the presentation by the art schools and in a gallery which was easily passed by.

\section{The House as an Exhibition Format}

The exhibitions in the Belgian Section, which used the concept of the house as a format to advertise home-related or other commercial products, generally assigned greater prominence to the theme of the domestic interior. The Agriculture, Horticulture and Cattle-breeding Group, for example, opted for a model farm as one of their main attractions. The Electric and Hydraulic Energy Pavilion gave a central place to a life-size model of an 'electric' house. The Five Warehouses Pavilion was 
devoted to the theme of 'living in the year 2000'. And so on. As this article will show, a close reading of the above-mentioned pavilions clearly reveals the increasingly problematic situation of certain anti-commercial, 'good' living discourses vis-à-vis the rapid development of powerful consumer accounts of contemporary living.

\section{The Model Farm}

The Model Farm shown by the Agriculture, Horticulture and Cattle-breeding Group (Group 16) in particular raises questions concerning the involvement of one of the very active contemporary 'good home' advocates outside the Expo site: the Boerinnenbond (Farmers' Wives' Union), a Flemish, Catholic, socio-cultural organisation of farmer’s wives. [fig. 13] The farm was meant to be one of this group's most important attractions on the exhibition site. Together with the other pavilions in this area - an auction-mart, several exhibition halls, a restaurant, a department store, etc.

- it was meant to promote Belgian agricultural products and encourage contemporary farming. ${ }^{48}$ In order to achieve this goal, the Agriculture Subgroup - which supervised the design and the construction of the Model Farm - considered it as realistic as possible. The farm existed of a onestorey farmhouse and an adjacent stable, designed by Harry Courtens and Marcel Dams, and was surrounded by a vegetable garden and a field with grazing cows. Furthermore the house contained a 'real' household. For the duration of the World's Fair a farmer, Jan Van Hyfte, his wife and children exchanged their home for the dwelling at the Brussels exhibition. Lastly, the realistic appearance of the model farmhouse was reinforced by its explicitly private nature: the exhibition home was not open to the public. To enter it, one had to ring the doorbell. The inside of the exhibition house was only visible through the windows or by means of a few publications in magazines. $^{49}$

Although it was private, special attention was paid to the interior of the farmhouse. The various rooms, defined by a simple architectural layout, were comfortably equipped with light, modern 
furniture and contemporary sanitary fittings. 'Modernity' was present in the open relationship between office, living room, dining area and kitchen, as well as in the explicit presence of a new medium: television. But one overriding rule had to be followed. As was stipulated in a report of July 1955, the design of the farmhouse was not to be 'beyond the pocket of the manager of a medium-sized farm'. 50

The stress put on the social correctness and modesty of the Model Farm brings to mind the Boerinnenbond's contemporary plea for good rural living. ${ }^{51}$ Since 1953 these farmers' wives had built several fully equipped 'dream houses' which - on the occasion of the Boerinnendagen (the Farmers' Wives' Days) - each time received a huge number of visitors. These ideal country homes - described as perfect 'love nests' for Christian families - were the result of ongoing thorough research into contemporary farmers' housing needs and wishes and cautiously introduced modernity into the traditional farmhouse. ${ }^{52}$ Although the Boerinnenbond was a member of the Committee of the Agriculture Subgroup, its participation in the establishment of the Expo farm did not express a commitment similar to that of the organisation of their 'dream houses'. Compared with the series of articles on the '1958 Dream House', built by the Boerinnenbond in the Ghent Casino, their periodical Bij de haard paid only minimal attention to the model farmhouse at the World's Fair. ${ }^{53}$ Whereas almost every room in the first house was discussed and analysed in relation to the daily needs of the 'Christian family' and the comfort of the housewife, not one picture of the latter was published in this magazine. ${ }^{54}$ Although the reasons for the moderate enthusiasm of the Boerinnenbond were not expressed, it is quite clear why the Expo farmhouse was not part of the series of 'dream houses'. The ideal or 'dream' homes of the Boerinnenbond were elaborate mixtures of contemporary architectural features - wall units, an open kitchen and living space, etc. - and items from the traditional dwelling - e.g. the primacy of the back door entrance, the maintenance of the parlour as a 'multi-functional' room - as well as so-called home improvements 
introduced by the members of the organisation such as a hatch between the kitchen and the store room. Compared to these houses, the Expo farmhouse was far more the product of an architect with just a few smart 'inventions', such as the window in the kitchen and the bedroom overlooking the stables. Furthermore it is not unthinkable that the enthusiasm of the Boerinnenbond for the Expo in general was rather limited. De Boer, the periodical of the Boerenbond (Farmers' Union), the male counterpart of the Boerinnenbond, clearly indicates that a significant number of farmers were of the opinion that the World's Fair was a real 'fair for adults', full of misleading attractions. One can imagine that the farmers' wives were troubled by the highly entertaining character of the Expo as a setting for their promotion of modest, 'do-it-yourself' modern living.

\section{The Electric House}

Most of the other pavilions in the Belgian Section that used the house as an exhibition format displayed different messages when it came to modern domesticity. The Electric House in the centre of the Electric and Hydraulic Energy Pavilion and the theme 'living in the year 2000' expressed by the Five Warehouses Pavilion focused mainly on the wonders and joys of a modern consumer lifestyle instead of struggling with 'good homes’ messages. Once again, comfort, hygiene and design are key words when describing the references made to domestic issues in these pavilions. However, these terms again acquired different meanings.

The Electric House, for example, was part of the Domestic Appliances Subgroup (Subgroup 5) of the Electric Energy Group (Group 11) and was meant to promote the use of electricity and electrical household equipment. ${ }^{55}$ [fig. 14] It was designed by the abovementioned Jacques Dupuis together with Lou Bertot, a duo that was in fact responsible for the entire interior decoration of the Electric and Hydraulic Energy Pavilion. On a circular platform with a diameter of sixteen metres, a living room, a kitchen, two bedrooms, a bathroom and a laundry room - all equipped with sophisticated electric appliances - were arranged around a central patio. The platform rotated slowly in order to 
let the visitor - who was not allowed to enter the house - enjoy the domestic scenery as if watching a roundabout. By taking the escalator to the top floor, this entertaining experience could be combined with a panoramic view from above the house. The committee of Subgroup 5 considered the Electric House to be the most important part of their exhibition. Their president, D'Hooghe, was convinced that 'more and more of the visitors' interest (in general) is focused on homes', a statement that was verified by a visit of a delegation from the committee to, amongst other things, the 1956 French 'Salon des Arts Ménagers’ (with La Maison Tout en Plastiques by Lionel Schein) and the 1956 ‘Daily Mail Ideal Home Exhibition’ in London (including the Smithsons’ House of the Future). ${ }^{56}$ For this reason the committee decided to give the Electric House a central place in their display. Even in the overall layout of the pavilion the model home functioned as a climax that could only be reached after passing through the other subgroups: Production, Transportation, Distribution and Industrial Applications of Electric Energy. An inquiry into public opinion in Belgium regarding the 'success' of the World's Fair illustrates the effectiveness of the abovementioned exhibition strategy. ${ }^{57}$ The Electric Energy Pavilion was mentioned in the list of ‘preferred pavilions' specifically because of its model house.

The Electric House was of course the perfect way to add human scale to the exhibition and to express the central theme of the group: 'Electricity serving mankind'. But it was also one of the few means left by which to astonish the public with future or 'new' wonders of electricity - a theme that, since the invention of electricity, had played an important role in World Exhibitions. ${ }^{58}$ The committee of Subgroup 5 assembled the most recent electric household appliances in the house, produced both in Belgium and abroad (especially in America). It was stipulated that this equipment had to be 'avant-garde in its appearance as well as in terms of the applied techniques'. ${ }^{59}$ One of the appliances, greatly admired in the popular press, was an electric oven, which was at the same time a deep-freezer with compartments for every day of the week. ${ }^{60}$ By pushing a few buttons this machine would prepare all the necessary meals at the required time. To gain the public's full attention, 
Subgroup 5 did not apply educational techniques, nor did it present the electric appliances as products of a high culture. Instead all the electric goods were exhibited as the props of a highly fashionable theatre scene. In an initial design the show-house was literally part of an amphitheatre. Although this plan was never carried out, the final circular platform still resembled a stage. During visiting hours three hostesses played the role of inhabitants and even in brochures the 'dream house' was presented as theatre scenery, watched from the side by several spectators.

Unlike the approach in the Buildings and Dwellings Pavilion, the Social Housing Pavilion, the presentation of the Applied Arts Subgroup and the model farm, the Electric House did not present such themes as 'design', 'hygiene' and 'comfort' as social, cultural or building qualities. Instead they were used as a set of tools to express the general consumer message propagated by the showhouse. Electricity was applied to the most extraordinary functions: the water supply in the bathroom, a video camera to keep an eye on the children's room, closing doors, etc. The kitchen almost freed the inhabitants from cooking but, as it is one of the most substantial rooms when it comes to electricity consumption, nevertheless took up a quarter of the living area. The beautifullylit bathroom was able to turn the necessary bodily hygiene into a pleasant daily experience. Breakfast could be made and consumed without getting out of bed. The highly fashionable, roundedged objects and often foldable furniture promoted a lifestyle of consumption and leisure. In a way, the Electric House resembled the Smithson’s 1956 House of the Future mentioned above. Both patio-houses refer explicitly to American design and lifestyle, but they did so for different reasons. According to Sarah Williams Goldhagen, the House of the Future, together with other contemporary designs by the Smithsons, was first and foremost meant to generate a more authentically lived experience of daily life, free from the dominance of social convention. This experience was stimulated by the interior organisation of the home. Almost every room of the House of the Future was focused on a central glazed patio 'onto which Mr. and Mrs. John Citizen were forced to gaze - and thereby perhaps to reflect - during exhausted daily enactments of 
domestic ritual: washing dishes, rinsing one’s hands in the master-bedroom washbasin, bathing in the house's only bathtub' ${ }^{61}$ The biomorphic design of the House of the Future was mainly the result of the Smithsons' choice of using plastic - then a promising new building material - combined with their strong belief that materials should be used and experienced according to their specific characteristics. The smooth, round-edged form of the 'ideal home' would not only remind the viewers of plastic’s ‘fluid' origins, but also take best advantage of a substance that could be moulded into virtually any shape except the right angle.

Compared to the House of the Future - which according to Reyner Banham had been styled like an American car $^{62}$ - the design and the underlying motivations of the Electric House at the Expo were far more moderate. Instead of expressing existential reflections concerning homes in a consumeroriented world, the model house by Dupuis and Bertot - a painted wooden construction - was first and foremost a modernist exercise in contemporary exhibition architecture and design. A close reading of its internal organisation even reveals that the model home could not really function as a home. Contrary to the House of the Future, the Electric House developed centrifugally away from its internal patio, thus creating ideal show rooms, which were indirectly lit in order to dematerialise the architectural surroundings. [fig. 15] But in unfolding the house, the entrance hall - a feature to which Dupuis, in his designs for 'real' houses, devoted much attention - was eliminated. ${ }^{63}$ Added to his otherwise crucial concern for the protection of the intimacy of the home, one can conclude that, in relation to this project, Dupuis was not primarily engaged with habitational issues. Instead of contemplating the way the exhibited electric appliances affect contemporary domestic living, the Electric House was a hybrid combination of modernist exhibition architecture and the glorification of lifestyle consumption. 


\section{The Five Warehouses Pavilion}

The Five Warehouses Pavilion revealed a similar double identity. Just as in the Electric House, consumer messages related to the domestic sphere were not questioned or discussed, but ended up being encased in or linked up with a genuine modernist language. The Five Warehouses Pavilion a project by the architects Jean Petit, Jean Plumier and Jean and André Polak - represented the participation of five Belgian department stores: A l'Innovation, Au Bon Marché, Galeries Anspach, the Antwerp Grand Bazar and the Grand Bazar in Liège. ${ }^{64}$ The pavilion consisted of two separate parts: a restaurant and an exhibition hall. For the interior design of the exhibition hall, a competition was organised in which designers were asked to interpret 'life in the year 2000'. ${ }^{65}$ The competition was won by the Finnish designer Tapio Wirkkala, whose project was quite exceptional and unusual compared to his other work of the period. In four polygonal window displays, Wirkkala presented several areas and aspects of future living: a living room, a beauty salon, a new urban development and a children's room. The fifth window display in the exhibition hall was preserved for 'the eternal feminine': a presentation of women's fashion in the year 2000 by the French décorateur Olivier Adnet. In Wirkkala's designs for the future, lifestyle promotion was intertwined with references to a modernist discourse, but without pointing out the problematic character of this combination. In the living room, for example, whose atmosphere was artificially regulated, several design objects by Wirkkala - such as the chair of laminated birch and bent plywood, produced in 1957 - were shown as part of a fashionable and consumer style of living. [fig. 16] An early form of microwave oven prepares all the dishes and shopping is made easier by the installation of a direct railway connection through the air to a huge warehouse in the city centre. The luxury of the imagined domestic sphere contrasts sharply with the sparse modernity and austerity of the contemporary exhibitions on Finnish arts and applied art in Western Europe, many of which were designed by Wirkkala. ${ }^{66}$ Even at the Expo itself this contrast was visible. Apart from the lifestyle promotion in the Five Warehouses Pavilion, Wirkkala also designed the exhibition in the Finnish Pavilion: a familiar 
presentation of Finnish culture characterised by a sharp clair obscur, a prevailing sense of

emptiness and overwhelming images of the national landscape.

\section{Conclusion}

The presence of the home in the Belgian Section of Expo 58 ranges from an exhibition subject to an exhibition format, covering several forms in between. Various aspects of modern habitation were tackled, depending on the participant's motives: presenting national progress and/or educating the public and/or advertising home-related products. The resulting compound image of the modern home reflects the then fragmented national debate on domestic living. More specifically it reveals the increasing conflict between a modernist perspective that very much insisted on the moral content of the home, and a consumer perspective, promoting instantly accessible dreams. As the presentations by these groups, which were meant to stimulate 'good' living, lacked a coherent approach, the tempting power of the commercially-oriented participants is not to be underestimated. The INL had lost its fight for a well-coordinated presence of the home in the Belgian Section. The Buildings and Dwellings Group could only preserve a diluted version of their ‘synthesis’ of all national housing problems. In the meantime the promotion of a contemporary lifestyle, on and outside the World's Fair site, outpaced the discourse on the domestic interior.

\section{Fredie Floré, Mil De Kooning}

\footnotetext{
${ }^{1}$ See, e.g., F. Floré, M. De Kooning, 'Formes Nouvelles and the communication of modern domestic ideals in postwar Belgium', ADDITIONS to architectural history: XIXth annual conference of the Society of Architectural Historians, Australia and New Zealand (Available on CD-ROM), SAHANZ, 2002, s.p.; M. Ferran-Wabbes, Jules Wabbes 19191974: binnenhuisarchitect, La Renaissance du Livre / Dexia, 2002; M. De Kooning, F. Floré, I. Strauven (eds.), Alfred Hendrickx en het fifties meubel in België, Vakgroep Architectuur en Stedenbouw, Universiteit Gent / Stedelijke Musea Mechelen, 2000; M. De Kooning, Willy Van Der Meeren. Architectuur Stedebouw Design Research Onderwijs, Faculteit Toegepaste Wetenschappen, Universiteit Gent (unpublished Ph.D. thesis), 1997. Apart from these academic studies, several surveys and oeuvre-catalogues provide information on post-war avant-garde design in Belgium. See e.g. F. Defour, Belgische meubelkunst in de XXe eeuw. Van Horta tot heden, Lannoo, 1979; J. Vanderperren, L. Daenens (preface), 25 jaar Pieter De Bruyne - meubels, Stad Gent / Museum voor Sierkunst, 1980; H. Gaus (ed.), De fifties in België, ASLK, 1988; M. De Kooning, Willy Van Der Meeren, Laat-XXe-eeuws Genootschap, 1993; G. Bekaert, H.
} 
Claus, L. Daenens, F. Defour, J. De Geest, M. Galle, P. Restany, M. Yonekura, H. Balthazar (preface), Emiel Veranneman. 50 jaar meubelcreaties, Gemeentekrediet, 1994; G. Bekaert, A. Branzi, F. Burkhardt, L. Daenens, Ch. Kieckens, M. C. Smout-Baeyens, Design Made in Belgium 1900-1994, Stichting Interieur, 1994; M. E. Bucquoye, L. Daenens, M. De Kooning, M. Dubois, F. Floré, Ch. Kieckens, E. Pil, N. Poulain, Forms From Flanders. From Henry van de Velde to Maarten Van Severen. 1900-2000, Ludion, 2001.

${ }^{2}$ See, e.g., W. Van Moorsel, Contact en controle. Het vrouwbeeld van de stichting Goed Wonen, Uitgeverij Sua, 1992.

${ }^{3}$ See, e.g., T. De Rijk, Het elektrische huis. Vormgeving en acceptatie van elektrische huishoudelijke apparaten in Nederland, Uitgeverij 010, 1998; R. Oldenzielen, C. Bouw (eds.), Schoon genoeg. Huisvrouwen en huishoudtechnologie in Nederland 1898-1998, Uitgeverij SUN, 1998.

${ }^{4}$ See, e.g., I. Cieraad (ed.), At Home. An Anthropology of Domestic Space, Syracuse University Press, 1999 ; J. Huisman, I. Cieraad, K. Gaillard, R. van Engelsdorp Gastelaars, Honderd jaar wonen in Nederland 1900-2000, Uitgeverij 010, 2000.

${ }^{5}$ Fredie Floré is currently working on the Ph.D. project on Interior and modernity in post-war Belgium, under the supervision of Professor Mil De Kooning. It is part of the research performed by the Architectural Theory and History research group at the Department of Architecture and Urban Planning, Ghent University. Other current Ph.D. projects concerning the history of modern architecture in Belgium are The architecture of Expo 58 by Rika Devos and Victor Bourgeois and the modern movement in Belgium. Between radicalism and pragmatism by Iwan Strauven.

${ }^{6}$ B. Schroeder-Gudehus, D. Cloutier, 'Popularizing science and technology during the Cold War: Brussels 1958', in R. W. Rydell, N. E. Gwinn (eds.), Fair Representations. World's Fairs and the Modern World, VU University Press, 1994, pp. 157-180.

${ }^{7}$ P. Van Wesemael, Architecture of instruction and delight? A socio-historical analysis of World Exhibitions as a didactic phenomenon (1798-1851-1970), 010 Publishers, 2001.

${ }^{8}$ B. Colomina, 'The exhibitionist house', in R. Ferguson (ed.), At the end of the century. One hundred years of architecture, The Museum of Contemporary Art, 1998, pp. 126-165.

${ }^{9}$ L.-L. Sosset, 'In het teken van de wereldtentoonstelling. Binnenhuisarchitecten te Brussel en te Luik', Guide Intérieur Gids, no. 485, 1958, pp. 20-25.

${ }^{10}$ The Urbanism Pavilion explicitly focuses on good home issues on the urban scale and is therefore situated beyond the scope of this paper.

11 The De Taeye Act was passed on 29th May 1948, having been proposed by the CVP, the Catholic party in government. The Brunfaut Act dates from 15th April 1949 and was a counter-proposal by the BSP, the Socialist party.

${ }^{12}$ The Brunfaut bill dates from 27th January 1948. The content of the bill and the development of the "war of amendments’ are described in L. Goossens, Het sociaal huisvestingsbeleid in België. Een historisch-sociologische analyse van de maatschappelijke probleembehandeling op het gebied van het wonen, Faculteit der Sociale Wetenschappen, Katholieke Universiteit Leuven (unpublished Ph.D. thesis), 1982.

${ }^{13}$ As Belgium is a bilingual state, many national organisations have a French and a Dutch name. The INPH for example is also called Nationaal Instituut tot Bevordering van de Huisvesting (NIBH), which can be translated as National Society for Housing Promotion. For the ease of the reader, the author only uses the French names of national organisations in the text. The Dutch synonyms and English translations are mentioned in the endnotes.

${ }^{14}$ The Dutch synonym of Société Nationale des Habitations et Logements à Bon Marché is Nationale Maatschappij voor Goedkope Woningen en Woonvertrekken (National Society for Cheap Housing and Homes). That of Société Nationale de la Petite Propriété Terrienne is Nationale Maatschappij voor de Kleine Landeigendom (National Society for Small Landowners). The Dutch synonym of the Fonds du Logement de la Ligue des Familles Nombreuses de Belgique is Woningfonds van de Bond der Kroostrijke Gezinnen van België (Housing Fund of the Association of Large Families in Belgium). That of the Caisse Générale d'Epargne et de Retraite is Algemene Spaar-en Lijfrentekas (General Savings and Annuity Bank).

${ }^{15}$ The INPH succeeded the non-profit organisation Institut National du Logement et de l'Habitation (INALA) or Nationaal Instituut voor Woning en Huisvesting (NIWHUIS) which more or less fulfilled the same tasks and was also established under the protection of the Ministry of Public Health and the Family. INALA can be translated as National Institute for Habitation and Housing.

16 'Pour un mobilier populaire', L'Habitation, no. 9, 1950, pp. 41-44.

${ }^{17}$ L'Habitation had a Dutch equivalent: Huisvesting (Housing).

${ }^{18}$ The Dutch synonym of the Office Provincial des Artisanats et des Industries d'Art du Brabant is Provinciaal Comité voor Kunstambachten en -nijverheden van Brabant (Provincial Committee of Arts and Crafts of Brabant). Brabant is situated in the centre of Belgium and includes Brussels. 'Logis 50'/‘Schoner Wonen' took place from $3^{\text {rd }}$ to $18^{\text {th }}$ of June 1950 in a huge tent near the Naamse Poort in Brussels. The departments of the French-speaking Catholic workers' movement involved with 'Le Foyer Populaire 1950' were: the Action Familiale Populaire (AFP), the Mouvement Populaire des Familles (MPF), the Equipes Populaires (EP) and the Ligues Ouvrières Feminines Chrétiennes (LOFC). 'Le Foyer Populaire 1950' took place from $3^{\text {rd }}$ to $26^{\text {th }}$ of June 1950 in the Palais d'Egmont in Brussels.

19 'Pour un mobilier populaire', L'Habitation, no. 9, 1950, pp. 41-44. 
20 'Le problème de l’habitation et l'exposition de 1958', L'Habitation, no. 2, 1955, pp. 156-162. A preliminary sketch for the general classification of the World Exhibition, designed by a private engineering firm, did propose a group titled 'the house', separate from a group concerning 'buildings and monumental arts'. In 1954 however this proposal was rejected by the commissioner general who was of the opinion that these two groups had to merge in order to form the group 'Buildings and Dwellings'. See E.V./H.S./40301, unpublished letter from Mr. E. Valcke to Mr. Hormidas, 8/9/1954, Archives of the Federal Government Service Economy, SME, Tradespeople and Energy, Expo 58 fund, no. 1215030 (preliminary numeration).

21 'L’habitation à l’Exposition de Bruxelles 1958', L'Habitation, no. 6-7, 1955, pp. 519-522.

22 Ibid.

${ }^{23}$ The Heysel Model District (1956-1963) was designed by the specially assembledAlpha team, including Renaat Braem, Victor Coolens, Jean Van Doosselaere, René Panis and the groups Structures and l'Equerre.

${ }^{24}$ Groupe 37. Edifices et Habitations, unpublished report containing the initial objectives of the Buildings and Dwellings Group, s.d., Archives of the Federal Government Service Economy, SME, Tradespeople and Energy, Expo 58 fund, no. 1215030 (preliminary numeration).

${ }^{25}$ R. T., 'Bruxelles 1958', Architecture 55, no. 15, 1955, p. 634. The preliminary design for the Buildings and Dwellings Pavilion might have been inspired by the 1951 proposals of the INPH as one of the members of the group committee, Jules Bary, was vice-president of the INPH in 1951.

${ }^{26}$ Réunion des deux présidents de groupe - Monsieur Bure et Monsieur Stynen -, des délégués du Village Modèle (dont M. Mertens Echevin de la Ville de Bruxelles) et d'un délégue du groupe La Santé, unpublished report, 13/10/1955, Archives of the Federal Government Service Economy, SME, Tradespeople and Energy, Expo 58 fund, no. 1218010 (preliminary numeration). This report shows that Mr Bure, president of the Urbanism Group, was of the opinion that the Buildings and Dwellings Group meddled too much with urbanism-related issues. Mr. Crappe, representing the Public Health Group, also believed that the Buildings and Dwellings Group exceeded its remit, especially to the detriment of the Family Health Subgroup, which was meant to promote healthy dwellings. The representatives of the Heysel Model District on the other hand expressed the concern that the 'ideal' housing block of the Buildings and Dwellings Group might harm the success of their 'realistic' project outside the Expo.

${ }^{27}$ Réunion du Conseil d'administration du 11 juillet 1958. Rapport présenté par le Groupe 37, unpublished report of a meeting of the Board of Administration, 11/7/1958, Provincial Archives of Antwerp, Léon Stynen fund.

${ }^{28}$ Marc Callewaert, 'Leert Expo 58 ons weer bouwen? Architectuur der toekomst in het land van de rieten daken', Zondagsvriend, no. 22, 1958, pp. 20-23.

${ }^{29}$ M. Lz., 'Les industries du bois', Le Soir, no. 112, 23 April 1958, p. 7.

${ }^{30}$ Réunion du Conseil d'administration du 11 juillet 1958. Rapport présenté par le Groupe 37, unpublished report of a meeting of the Board of Administration, 11/7/1958, Provincial Archives of Antwerp, Léon Stynen fund.

${ }^{31}$ The model house was designed by the architect Frans Vuye together with Gustave Creupelandt, both employees of the De Coene firm.

${ }^{32}$ F. Floré, 'De Coene na WOII: meubelproducent en bouwfirma', in M. De Kooning, R. De Meyer, F. Floré (eds.), van Moderne Makelij 1952-1977. De Kortrijkse Kunstwerkstede De Coene in Antwerpen, erfgoedcel Antwerpen, 2002, pp. 9-40.

${ }^{33}$ W. Van Der Meeren, 'Wonen op de Algemene Wereldtentoonstelling van Brussel 1958', Wonen, s.n., 12/1958, pp. 29-34.

${ }^{34}$ The Dutch synonym of INL is Nationaal Instituut voor de Huisvesting (NIH), which can be translated as National Housing Institute. The INL was established by the law of $27^{\text {th }}$ June 1956 and was an autonomous public institute under the protection of the Ministry of Public Health and the Family. It was meant to rationalise and coordinate the research, information and documentation concerning all housing-related issues. It took over the activities of the INPH, the Conseil supérieur du Logement et de l'Habitation or Hoge Raad voor Volkshuisvesting en Volkswoningen (High Council of Public Housing and Public Dwellings), the Conseil Supérieur de la Construction d'Habitations pour Ouvriers Mineurs (High Council for the Erection of Miner's Dwellings) and the study and research centre of the Société Nationale des Habitations et Logements à Bon Marché.

${ }^{35}$ Nationaal Instituut voor de Huisvesting. Notulen van de 40e vergadering van het Beheerscomité, unpublished report, 22/01/1953, Archives of the Société de Logement de la Région Bruxelloise, INL fund. See also: C. Crappe, 'Een tentoonstelling leerde ons', Wonen, s.n., 12/1958, pp. 5-22.

${ }^{36}$ The Social Housing Pavilion was a project of the Social Housing and Health non-profit organisation, which was specially established for the World's Fair. This organisation was presided over by Cyrille Crappe and included representatives of the INL, the Société Nationale du Logement, the Société Nationale de la Petite Propriété Terrienne, the Fonds du Logement de la Ligue des Familles Nombreuses de Belgique, the Caisse Générale d'Epargne et de Retraite and the Fédération Royale des Sociétés d'Architectes de Belgique (Royal Union of Belgian Architects' Organisations).

${ }^{37}$ Communication téléphonique de Monsieur Bure, Pdt. du gr. L'Urbanisme à Monsieur Iweins de Wavrans, unpublished report, 4/4/1957, Archives of the Federal Government Service Economy, SME, Tradespeople and Energy, 
Expo 58 fund, no. 1218010 (preliminary numeration). See also: C. Crappe, 'Een tentoonstelling leerde ons', Wonen, s.n., 12/1958, pp. 5-22.

${ }^{38}$ The law of $27^{\text {th }}$ June 1956 allowed the Caisse Générale d'Epargne et de Retraite and the Société Nationale du Logement to grant loans for the furnishing of social dwellings and small country dwellings. The Société Nationale du Logement or Nationale Maatschappij voor de Huisvesting (National Housing Society) was established by the same law and was the result of a change of name of the Société Nationale des Habitations et Logements à Bon Marché.

${ }^{39}$ L. Aerts, K. Mertens, M. Van Hoof, De Belgische Meubelnijverheid. Problemen en perspectieven, Universitaire Boekhandel Uystpruyst, 1961.

${ }^{40}$ Concours national du meuble (catalogue), INL, 1958.

${ }^{41}$ The seven winning designs were the work of six designers: Roger Van Assche, Blondel and Raymond Van Loo, Paul Franck, Pieter De Bruyne and Guy Legrand, Apart from the president, Victor Bourgeois, the jury consisted of Mme. des Cressonières, Adelbert Van De Walle, Robert Van Tenten, E. Welch, J. Hamels, Max Bill (Switzerland), M. Gascoin (France), A. H. Huldt (Sweden) and J. Penraat (Netherlands). 29 designers and producers participated in the first round. ${ }^{42}$ No photographs of this part of the INL exhibition have been found. In an interview the author Lou Bertot states that the furniture itself was not presented in the Social Housing Pavilion. Contemporary descriptions do not indicate otherwise.

${ }^{43}$ Réunion des deux présidents de groupe - Monsieur Bure et Monsieur Stynen -, des délégués du Village Modèle (dont M. Mertens Echevin de la Ville de Bruxelles) et d'un délégue du groupe La Santé, unpublished report, 13/10/1955, Archives of the Federal Government Service Economy, SME, Tradespeople and Energy, Expo 58 fund no. 1218010 (preliminary numeration).

${ }^{44}$ Formes Nouvelles had a Dutch synonym: Nieuwe Vormen (New Forms). See: F. Floré, M. De Kooning, 'Formes Nouvelles and the communication of modern domestic ideals in postwar Belgium', ADDITIONS to architectural history: XIXth annual conference of the Society of Architectural Historians, Australia and New Zealand (Available on CD-ROM), SAHANZ, 2002, s.p. See also: M. De Kooning, Willy Van Der Meeren. Architectuur Stedebouw Design Research Onderwijs, Faculteit Toegepaste Wetenschappen, Universiteit Gent (unpublished Ph.D. thesis), 1997.

${ }^{45}$ In 1958 Van De Walle was also chairman of the Institut d'Esthétique Industrielle de Belgique et du Grand-duché de Luxembourg or Instituut voor Industriële Vormgeving voor België en het Groot-Hertogdom Luxemburg (Institute of Industrial Design of Belgium and the Grand Duchy of Luxembourg), a non-profit organisation that was established two years earlier and intended to stimulate the production of industrial design. At the time of the Expo this institute was strongly intertwined with Le Signe d'Or or Het Gouden Kenteken (Golden Sign), another non-profit organisation that was established in the same year. Echoing the Italian Compasso d'Oro, Le Signe d'Or yearly awarded a decoration to 'good design' products made in the Benelux. At Expo 58 it exhibited the selected objects (not necessarily domestic appliances) of 1958 in Exhibition Hall V as part of the Commerce Group. As this presentation did not explicitly tackle the problem of the home, it is not further discussed in this article.

${ }^{46}$ Tentoonstelling in 1958. Groep 2. De Kunsten en hun uitdrukkingsmiddelen. Klasse Toegepaste kunsten en kunstambachten, unpublished report, s.d., private archives of Adelbert Van De Walle.

${ }^{47}$ Pierre-Louis Flouquet, 'A l'Exposition de Bruxelles, au Palais 7. La section des créateurs ensenbliers', La Maison, no. 9, 09/1958, pp. 339-341.

${ }^{48}$ Verslag over de vergadering van het Comité van Groep XVI 'Land- en Tuinbouw, Veeteelt' van de Tentoonstelling Brussel 1958, belegd op 1 juli 1955 onder het voorzitterschap van de H. Parmentier, Secretaris-Generaal bij het Ministerie van Landbouw, unpublished report, 1/7/1955, Archives of the Federal Government Service Economy, SME, Tradespeople and Energy, Expo 58 fund no. 1213020 (preliminary numeration).

${ }^{49}$ H.N., 'Op de Expo staat een hoeve. In de schaduw van het Atomium melkt men koeien', De Boer, no. 29, 1958, pp. 8-9.

${ }^{50}$ Verslag over de vergadering van het Comité van Groep XVI 'Land- en Tuinbouw, Veeteelt' van de Tentoonstelling Brussel 1958, belegd op 12 juli 1955 onder het voorzitterschap van de H. Parmentier, Secretaris-Generaal bij het Ministerie van Landbouw, unpublished report, 12/7/1955, Archives of the Federal Government Service Economy, SME, Tradespeople and Energy, Expo 58 fund no. 1213020 (preliminary numeration).

${ }^{51}$ Since its establishment in 1911 The Boerinnenbond devoted special attention to good country living. From 1945 the Commissie voor Schone Hofsteden (Commission for Beautiful Farmsteads) - a study group that published the book De Boerenwoning (The Farmer's House) in 1945 - coordinated their housing campaigns.

${ }^{52}$ During the fifties the Boerinnenbond conducted several surveys of its members in order to evaluate their 'dream houses', their home publications and customs in contemporary rural homes.

${ }^{53}$ Bij de haard can be translated as Near the hearth.

${ }^{54}$ L.K., 'Wij en de Wereldtentoonstelling', Bij de haard, no. 5, 1958, pp. 137-138.

${ }^{55}$ B. Peeters, 'Het Elektrisch Huis \& het Paviljoen van de Elektrische Energie', unpublished student paper, Ghent University, Department of Architecture and Urban Planning, 2002.

${ }^{56}$ Comité de Classe V - Applications domestiques et artisanales. Procès-verbal de la séance tenue le 11 avril 1956 , unpublished report, 25/4/1956, Archives of the Federal Government Service Economy, SME, Tradespeople and Energy, 
Expo 58 fund, no. 1212040 (preliminary numeration). 'Salon des Arts Ménagers' can be translated as 'Exhibition of Domestic Arts', La Maison Tout en Plastiques as the Completely Plastic House.

${ }^{57}$ G. and E. Jacquemyns, L'Exposition de 1958. Son succès auprès les Belges. Opinions et voeux des visiteurs, Institut Universitaire d'Information Sociale et Economique, 1959, p. 96.

${ }^{58}$ D. E. Nye, 'Electrifying expositions, 1880-1939', in R. W. Rydell, N. E. Gwinn (eds.), Fair Representations. World's Fairs and the Modern World, VU University Press, 1994, pp. 140-156.

${ }^{59}$ Classe V: Applications domestiques et artisanales. Procès-verbal de la séance 7 mars 1956, unpublished report, 22/3/1956, Archives of the Federal Government Service Economy, SME, Tradespeople and Energy, Expo 58 fund, no. 1212040 (preliminary numeration).

60 'Au Palais de l'Electricité: la cuisine de l’an 2000', Le Soir Illustré, no. 1351, 1958, s.p.

${ }^{61}$ S. Williams Goldhagen, 'Freedom’s Domiciles: Three projects by Alison and Peter Smithson', in S. Williams Goldhagen and R. Legault (eds.), Anxious Modernisms. Experimentation in Postwar Architectural Culture, MIT Press, 2000, pp. 74-95.

${ }^{62}$ R. Banham, The New Brutalism: ethic or aesthetic?, Architectural Press, 1966, pp. 61-67.

${ }^{63}$ M. Cohen and J. Thomaes, Jacques Dupuis. L'Architecte, La Lettre Volée, 2000.

${ }^{64}$ A. Staessens and M. Van Holm, 'Het Paviljoen van de Vijf Warenhuizen op de Wereldtentoonstelling van 1958', unpublished student paper, Ghent University, Department of Architecture and Urban Planning, 2002.

65 A. Toikka-Karvonen, 'Tapio Wirkkalan tulevaisuuden maailma', Viikkosanomat, no. 16, 1958, pp. 10-13. Designer Raymond Loewy received the second prize in the competition, architect Bruno Munari the third.

${ }^{66}$ K. Davies, 'A geographical notion turned into an artistic reality. Promoting Finland and Selling Finnish Design in Post-war Britain c. 1953-1965’, Journal of Design History, no. 2, 2002, pp. 101-116. 